\title{
Psoriasis Related Gout Arthritis in the Big Toe Interphalangeal Joint: A Case Report
}

\author{
Recep 0̈ztürk®
}

Dr. Abdurrahman Yurtaslan Ankara Oncology Education and Research Hospital, Department of Orthopedics and Traumatology, Ankara, Turkey

Recep Öztürk, Spec. Dr.

\section{Correspondence:}

Spec. Dr Recep Öztürk

Dr. Abdurrahman Yurtaslan Ankara Oncology Education and Research Hospital, Department of Orthopedics and Traumatology, Ankara, Turkey

Phone: +905054634794

E-mail: ozturk recep@windowslive.com

Received : July 22, 2019

Revised : July 22, 2019

Accepted : October 10, 2019

\section{ABSTRACT}

In this study, we present the first report of a case of gout arthritis localized in the interphalangeal joint of the right foot first toe, which was related to psoriasis disease in a 40 -year-old male patient. Since the symptoms did not respond to conservative treatments, the patient was treated with surgery. Arthrotomy was performed to debride around the bones and intraarticular crystals. Then, pharmacological treatment was initiated and lifestyle changes were made. No recurrence of the symptoms was observed during a 24-month follow-up.

Keywords: Psoriasis, gout, interphalangeal, diagnosis

\section{AYAK INTERFALANGEAL EKLEMINDE PSÖRIAZIs İLişKILI GUT ARTRITi: OLGU SUNUMU}

ÖZET

Biz bu çalışmada 40 yaşında erkek hastada, psöriazis hastalığı ile ilişkili, sağ ayak 1. parmak interfalangeal eklem lokalizasyonlu gut artritinin ilk raporunu yayımlıyoruz. Belirtiler konservatif tedavilere cevap vermediğinden, hasta cerrahi olarak tedavi edildi. Artrotomi yapılarak, kemiklerin çevresi ve eklem içi yerleşimli kristaller debride edildi. Ardından farmakolojik tedavi ve yaşam stili değişiklikliği uygulandı. 12 aylık izlemde semptomların rekürrensi olmamıştır.

Anahtar sözcükler: Psöriazis, gut, interfalangeal, tanı

\section{out is an inflammatory type of arthritis caused by the precipitation of mono-} sodium urate (MSU) crystals in the synovial fluid and associated with hyperuricemia. It was described for the first time by Egyptians in B. C. 2640 (1). The prevalence of gout is reported as $1 \%$ increases with dietary factors (2). The incidence increases by aging and gout is more common among men. Definitive diagnosis of gout disease is best established by the demonstration of monosodium urate crystals in the synovial fluid or biopsy (3).

Although the triggering mechanism of the acute attack has been poorly understood, factors for the development of gout have been described (4). These include an increased level of uric acid, alcohol abuse, hypertension, the use of antihypertensives, increased body mass index (BMI) and familial history of gout (5). In addition, it has been reported that gout may be associated with persistent psoriasis especially in male patients and in those with other causes of hyperuricemia (6). 
Gout arthritis is most commonly seen in the metatarsophalangeal joint. Herein, we present a rare case of gout arthritis of the toe interphalangeal joint associated with psoriasis.

\section{Case report}

A 40-year-old male patient was referred to the outpatient clinic with complaints of swelling in the right foot first/big toe interphalangeal joint and discharge in the medial of the joint (Figure 1). At the same time, the patient had diffuse erythrosquamous lesions in the foot due to psoriasis (Figure 2).

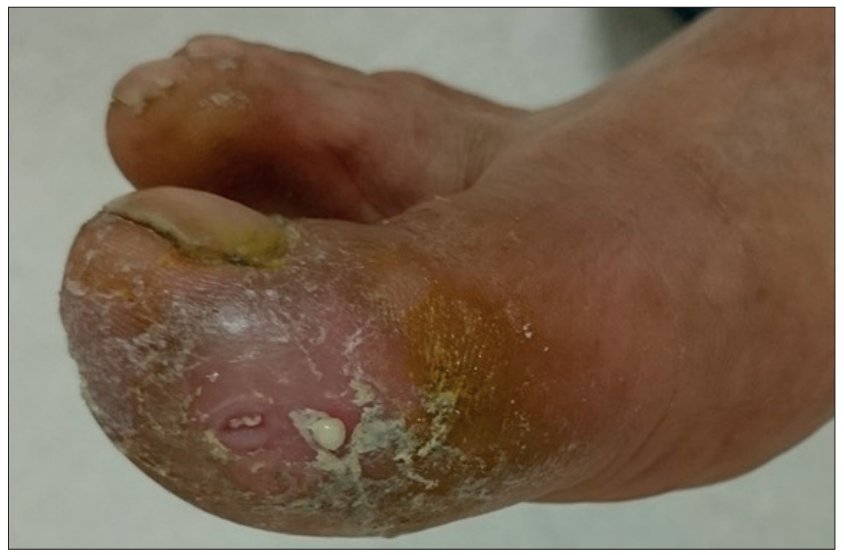

Figure 1. Ulceration and chalk-looking discharge in the medial of the foot first toe interphalangeal joint.

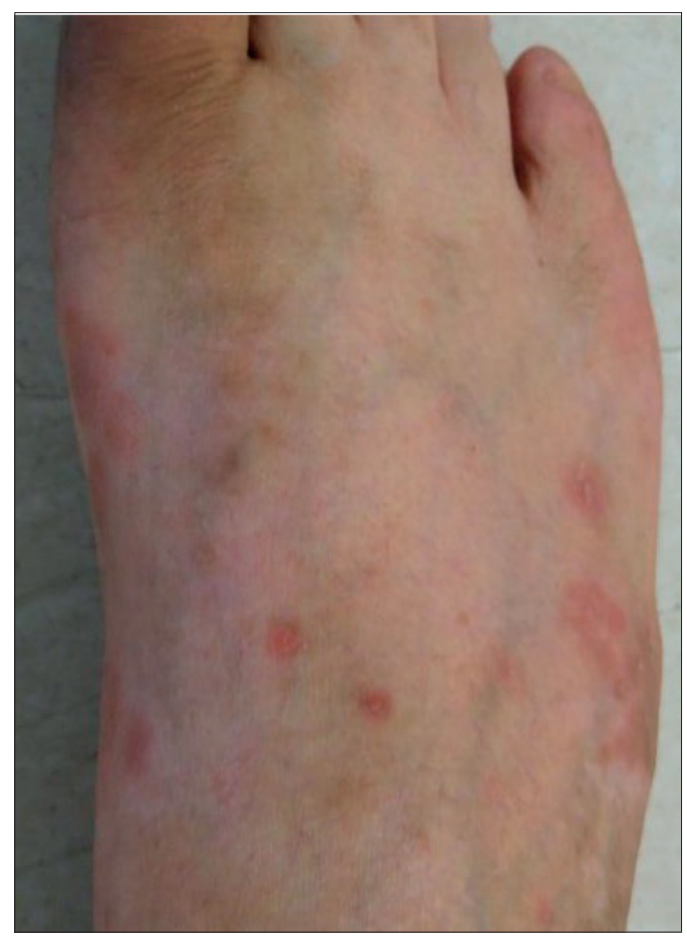

Figure 2. Psoriasis, right foot erytrosquamous lesions.
Written informed consent was obtained from the patient's legal custodian or first-degree relatives for publishing the individual medical records.

The medical history revealed that he had psoriasis for about 20 years and was continuing medical therapy. He had no diseases other than psoriasis. The patient reported that there are itching and pain localized in the interphalangeal joint of the right big toe for about 5 years, especially when he was eating meat. In addition, he stated that he had previously presented to various hospitals due to intermittent nocturnal pain and received analgesics. He had been diagnosed with gout disease which involved the toe interphalangeal joint in his presentation about two years ago. He had difficulty in wearing shoes due to a swelling that developed in his right toe interphalangeal joint about 6 months ago. The patient stated that a white-colored discharge began to leak from the medial to the swelling one month ago. The VAS score of the patient was $7 / 10$ at the time of admission. When previous drug use of the patient was examined/checked from the hospital system, the drugs he had used included colchicine $0.5 \mathrm{mg}$ tablet (gout disease), indomethacin $25 \mathrm{mg}$ tablet (psoriatic arthritis, gout), methotrexate $10 \mathrm{mg} / \mathrm{mL}$ injection solution (psoriasis), folic acid $5 \mathrm{mg}$ tablet (combined with methotrexate), 1 mg mometasone furoate $(0.1 \%)+50 \mathrm{mg}$ salicylic acid (S\%) pomade (psoriasis), and allopurinol $300 \mathrm{mg}$ tablet. He had no smoking or alcohol consumption. He did not state any familial or allergy history. The body-mass index was 27 .

The physical examination revealed swelling around the right foot first toe interphalangeal joint, without cellulitis. In addition, there were ulceration and white-colored discharge in the medial of the joint (Figure 1). Joint movements were highly restricted due to swelling and pain. There were no other swellings or tophi in the other joints of the patient.

On the anteroposterior and lateral direct radiography of the right foot, there were destructive and expansile lesions in the first interphalangeal joint (Figure 3). On the MRI ordered, there was a marginal erosion in the first interphalangeal joint with protruding margins that surrounded the adjacent soft tissues with moderate signals and suggested gout tophus (Figure 4). Laboratory outcomes were within the normal limits.

In the operating room, surgical decompression of right foot first interphalangeal joint of the patient was performed with a medial incision. The surgical approach was adequate to expose articular surfaces. Protrusions around 


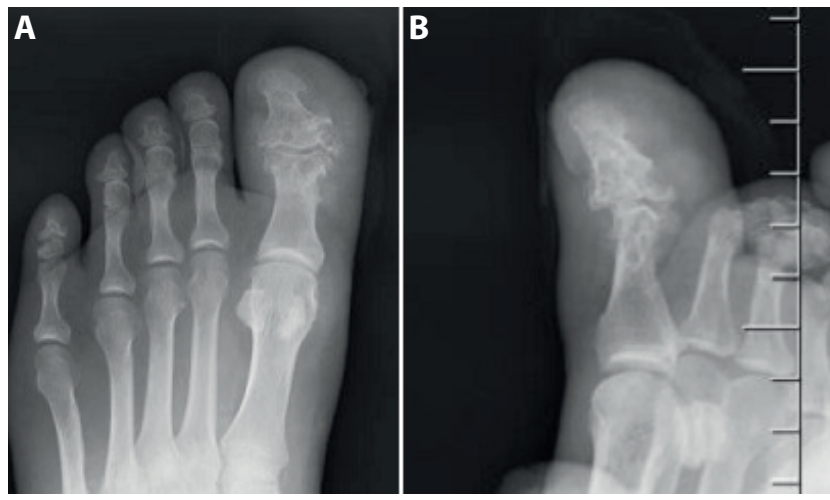

Figure 3. A, B. Right foot anterioposterior and lateral graphies, destructive and expansile lesion in the first toe interphalangeal joint.

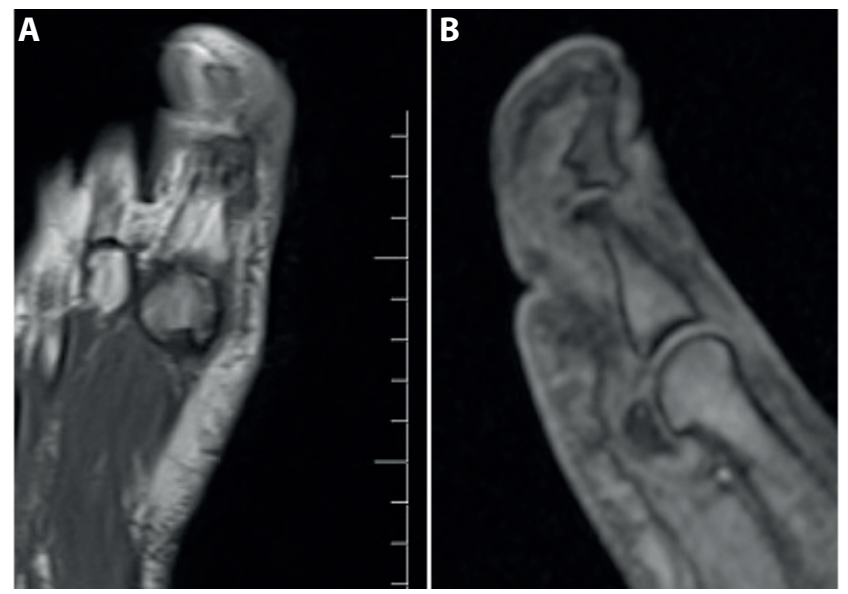

Figure 4. A, B. Right foot MR images, marginal erosion suggesting gout arthritis.

the joint were cleaned and the bone cavities were curetted (Figure 5). The material/debris obtained was sent for pathological examination. Debridement and pressured irrigation with the saline solution were carried out. Intraarticular $10 \mathrm{mg}$ triamcinolone was injected. The incision was gently sutured without pressing.

In addition, indomethacin $50 \mathrm{mg}$ three times a day was prescribed for 10 days. The patients gave a good response to the treatment and his VAS score on day 10 was decreased to $1 / 10$ from $7 / 10$. The histopathological examination was compatible with gout arthritis.

Wound healing occurred on day 30 (Figure 6). The patient had no symptoms during/in the postoperative month 24 .

\section{Discussion}

Gout is one of the most common inflammatory arthritis among adults (7). This disorder occurs due to hyperuricemia and the accumulation of monosodium urate crystals in the soft tissues and joints (8).

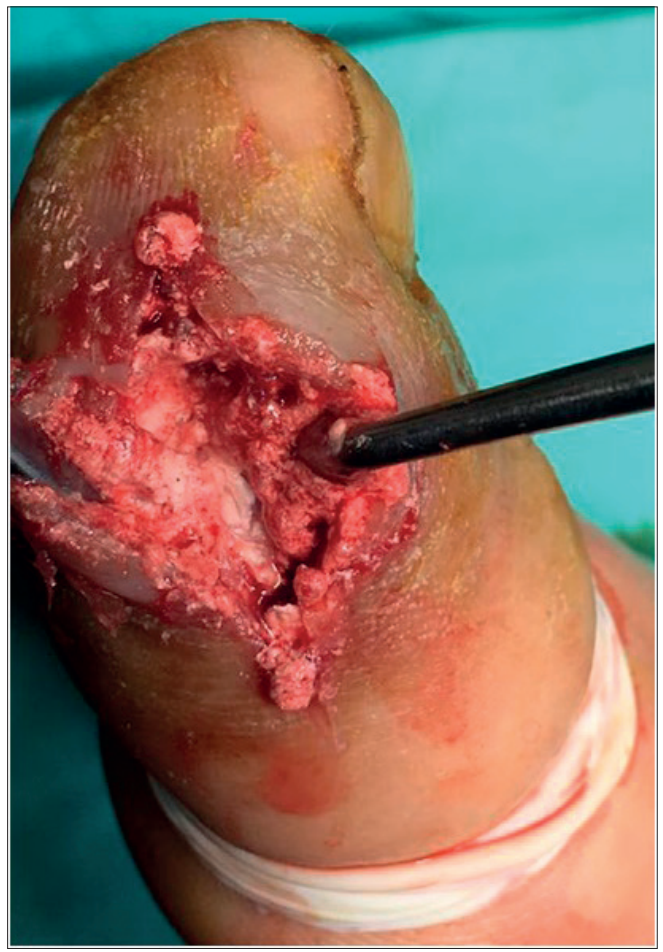

Figure 5. Intraoperative image, the debris consisted of white material corresponding to thick, chalk-looking tophus material.

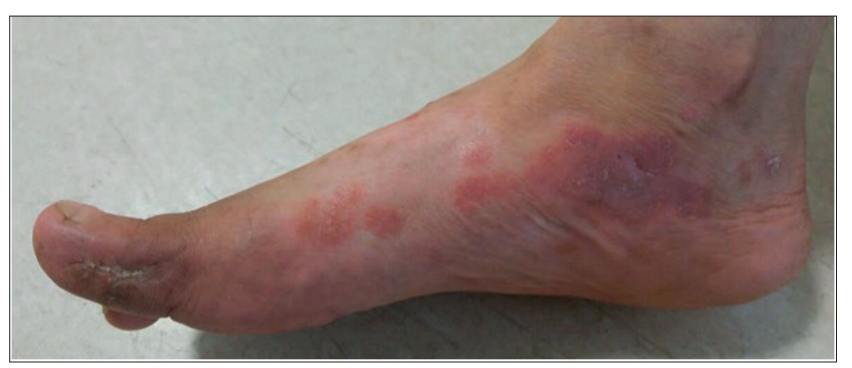

Figure 6. Full recovery was seen in the wound on the postoperative day 30 .

Chronic tophaceous gout usually follows repeated and untreated acute gout attacks. It gradually increases and insidiously occurs with a history of acute gout attacks, and may result in skin necrosis and ulceration through eroding atrophic superficial skin (9). In our patient, there were ulceration on the skin and chalk-looking discharge were seen after the attacks.

Hyperuricemia is seen in about one-third of the patients with psoriasis, and gout clinic accompanies in a part of these patients (6). Our patient had a history of psoriasis for about 20 years and stated that the symptoms in his first toe were exacerbating after protein-containing food. 
In the literature screening/review, we found only two cases of gout with the involvement of the interphalangeal joint. In the first case report published by Dobson et al. in 2012, an expansile lesion was described in the right foot first interphalangeal joint of an 80-year-old male patient who had no additional disease. In 2013, Alici et al. published a case of swollen soft tissue adjacent to the first interphalangeal joint due to the use of sildenafil in a 58-year-old male patient who had hypertension and coronary artery disease and was on antihypertensive medication. We think that our case report is the first of the interphalangeal joint localized gout disease associated with psoriasis.

Plain radiography and magnetic resonance imaging are usually helpful to understand the changes in the bone and soft tissues related to gout and thus, to differentiate from other joint diseases and tumoral lesions (10-12).

Gout disease has no specific treatment. Antihyperuricemic therapies may provide benefits, and low dose steroids may

\section{References}

1. Gaviria JL, Ortega VG, Gaona J, Motta A, Medina Barragán OJ. Unusual dermatological manifestations of gout: review of literature and a case report. Plast Reconstr Surg Glob Open 2015;3:e445. [CrossRef]

2. Luk AJ, Simkin PA. Epidemiology of hyperuricemia and gout. Am J Manag Care 2005;11:S435-42. https://www.ajmc.com/journals/ supplement/2005/2005-11-vol11-n15suppl/nov05-2216ps435-s442

3. Purohit MB, Purohit TM, Tandon RK. FNAC of gouty tophi -a case report. Indian J Pathol Microbiol 2006;49:42-3.

4. Wallace KL, Riedel AA, Joseph-Ridge N, Wortmann R. Increasing prevalence of gout and hyperuricemia over 10 years among older adults in a managed care population. J Rheumatol 2004;31:1582-7. http://citeseerx.ist.psu.edu/viewdoc/download?doi=10.1.1.1015.52 39\&rep=rep $1 \&$ type $=$ pdf

5. Alici T, Imren Y, Erdil M, Gundes H. Gouty arthritis at interphalangeal joint of foot after sildenafil use: A case report. Int J Surg Case Rep 2013;4:11-4. [CrossRef]

6. AlJohani R, Polachek A, Ye JY, Chandran V, Gladman DD. Characteristic and Outcome of Psoriatic Arthritis Patients with Hyperuricemia. J Rheumatol 2018;45:213-7. [CrossRef]

7. Zhang W, Doherty M, Pascual E, Bardin T, Barskova V, Conaghan P. EULAR evidence based recommendations for gout. Part I. diagnosis. Report of a task force of the Standing Committee for International Clinical Studies Including Therapeutics (ESCISIT). Ann Rheum Dis 2006;65:1301-11. [CrossRef] control the pain and inflammation $(13,14)$. Surgical treatment is indicated in cases refractory to medical therapy and suspected diagnosis (15). Surgical treatment may be simple as squeezing the pasty tophaceous material and fluid aspiration, but sometimes surgical decompression may be needed. Following surgical decompression, pharmacological treatment and lifestyle modifications are of paramount importance. ${ }^{5}$ In our report, there was a chronic gout case refractory to the treatment. Skin ulceration and discharge developed, and the patient significantly benefited from the surgical decompression and pharmacological treatment.

\section{Conclusion}

In summary, gout disease with the involvement of the foot first toe interphalangeal joint is rare, and to our knowledge, psoriasis associated gout disease has not been previously reported in the interphalangeal joint. Multidisciplinary treatment is critical in chronic cases.

8. Neogi T. Clinical practice, Gout. N Engl J Med 2011;364:443-52. [CrossRef]

9. Dobson M, Alwahab Y, Fazal MA. Interphalangeal joint involvement of the big toe in gout: a rare presentation. J Am Podiatr Med Assoc 2012;102:256-8. [CrossRef]

10. Bousson V, Hamzé B, Wybier M, Daguet E, Parlier C, Petrover D, et al. Soft tissue tumors and pseudotumors of the foot and ankle. J Radiol 2008;89:21-34. [CrossRef]

11. Öztürk R, Arıkan ŞM, Şimşek MA, Özanlağan $E$, Güngör BŞ. Management of solitary fibrous tumors localized in extremity: case series and a review of the literature. Eklem Hastalık Cerrahisi 2017;28:121-7. [CrossRef]

12. Öztürk R, Arıkan ŞM, Bulut EK, Kekeç AF, Çelebi F, Güngör BŞ. Distribution and evaluation of bone and soft tissue tumors operated in a tertiary care center. Acta Orthop Traumatol Turc 2019;53:189-94. [CrossRef]

13. Ochoa CD, Valderrama V, Mejia J, Rondon F, Villaroya N, Restrepo JF, et al. Panniculitis: another clinical expression of gout. Rheumatol Int 2011;31:831-5. [CrossRef]

14. Weberschock T, Gholam P, Hartschuh W, Hartmann M. Gouty panniculitis in a 68-year-old man: case report and review of the literature. Int J Dermatol 2010;49:410-3. [CrossRef]

15. Martin D, Joliat GR, Fournier P, Brunel C, Demartines N, Gié O. An unusual location of gouty panniculitis: A case report. Medicine (Baltimore) 2017;96:e6733. [CrossRef] 